\title{
How can the skills of Early Years leaders support other leaders in a primary school setting?
}

Management in Education 2017, Vol. 3I(3) I25-134

(C) 2017 British Educational Leadership Management \& Administration Society (BELMAS)

Reprints and permission:

sagepub.co.uk/journalsPermissions.nav DOI: 10.1 I77/08920206177| II94

journals.sagepub.com/home/mie

(S)AGE

\author{
Malini Mistry \\ University of Bedfordshire, Bedford, UK \\ Krishan Sood \\ Nottingham Trent University, Nottingham, UK
}

\begin{abstract}
This study investigated the leadership skills Early Years leaders demonstrated through their daily practice of teaching, assessing and teamwork within their setting. It explored how revealing the potential of Early Years leaders could have a positive impact on the leadership practice of other leaders in the same setting to improve pupil outcomes. A qualitative approach using interviews with Early Years leaders in 20 primary settings from the East Midlands and Bedfordshire areas was undertaken by two academics from two different UK based universities. Ethical guidelines ensuring anonymity and trustworthiness were followed. Using verbatim comments, data were analysed in themes against contemporary Early Years literature. Findings showed the skills of Early Years leaders could support pedagogy and practice but some of these skills were not utilized beyond this age phase. Our conclusion suggested that Early Years leaders had a range of leadership skills which were deemed specialist as they were unique to the success of the age phase, but needed to be exposed beyond Early Years for wider success and impact.
\end{abstract}

\section{Keywords}

Early Years, impact on learning, leadership, leadership development, specialist skills

\section{Introduction}

We define a leader in a school setting as someone with leadership or a formal role such as head teacher, principal, deputy head, vice-principal, assistant head, key stage leader, or subject leader in primary settings in England. However, in recent years, leadership thinking has changed from leadership residing primarily with the head teacher to a more shared leadership contributing to 'leadership density and capability' (Bush, 2015: 671). Aubrey found a 'serious lack of leadership development' for Early Years leaders, signifying that they may be 'under-prepared for their complex leadership role' (Aubrey, 2011: 13). Leadership is a complex role as it has become multi-faceted with many aspects to the role, from leading pupil learning to leading staff. We consider leadership in Early Years is a complex role because it requires different skills than for the primary phase, both requiring skills to manage a complex school environment (Brundrett et al., 2006; Crow, 2006). It is understandable why Early Years practitioners may feel daunted and overwhelmed with having to lead complexity with little specific preparation and development. Sackney and Walker's (2006) study of beginning principals in the United States found that Early Years leaders were not prepared for the pace of the job and felt unprepared for the loneliness of the position.

Furthermore, Rodd (1996) suggested that Early Years professionals may have a narrow view of leadership in terms of exactly what it entails, and Bricker (2000) went on to indicate that very few people have both Early Years and leadership skills, hence the importance to investigate this issue. Mistry and Sood (2015) reported that Early Years leaders had sound professional knowledge but lacked confidence in leadership concepts as they had little leadership recognition and development opportunities, which was also endorsed by Freeman and Brown (2000). This article focuses firstly on what leadership in the context of Early Years means. The discussion then moves to the skills necessary in being a good Early Years leader, and in particular it focuses on what specific specialist leadership skills are necessary in supporting other leaders. Finally, we touch on the impact of these skills on practice (pupils and adults).

\section{Literature}

This section focuses on literature on specific themes divided into key sections: Leadership in Early Years, Leadership skills, and Specialist leadership skills in Early Years, using leadership skills to support other leaders.

Corresponding author:

Malini Mistry, University of Bedfordshire, Polhill Avenue, Bedford, MK4I 9EA, UK.

E-mail:malini.mistry@beds.ac.uk 


\section{Leadership in Early Years}

Some literature suggests that the concept of leadership is problematic (Armstrong, 2009; Bush, 2015), with Muijs and Harris (2007) maintaining that it still remains undeveloped in the Early Years sector as some Early Years leaders have a narrow view of leadership. One reason for this could be that Early Years leaders have limited 'time and space' (Simpson, 2015: 6). Early Years leaders have numerous skills to lead learning and manage staff effectively, but Aubrey (2011) has found that many such Early Years leaders do not consider themselves as leaders, preferring rather to be known as teachers as they remain unsure about the training and development opportunities for the leadership role. Furthermore, they also had anxiety over the complexity of this role (Muijs et al., 2004; Moyles, 2006). According to Hargreaves (2011), not all primary schools have a dedicated programme of mentoring and coaching for staff identified with leadership potential, so there are fewer opportunities for their growth and development envisioned in system leadership. This implied that with no support or no real commitment to enable aspiring leaders to try out their developing leadership skills the professional development of these leaders was severely limited (Howland, 2013).

Recommendations for the Early Years Foundation Stage (EYFS) by Tickell (2011) suggested a better link between leadership qualifications and the impact of this on career structure in the maintained sector (specifically schools). This was also endorsed in the Nutbrown Report (2012), which promoted the virtues of continuing professional development for all those who work with young pupils. Teather (2011) announced that the Department for Education (DfE) had pledged a spending review settlement for Early Years' services, including recruitment and deployment of graduate leaders and continuing support for children's centre leadership through the National Professional Qualification in Integrated Centre Leadership. The independent report by Tickell (2011) on the EYFS had also recommended a progressive structure for qualifications, linking these to leadership qualifications and identifying clear career pathways for leaders and practitioners. Furthermore, Sellgren (2016) has recently reported that all nurseries in England should have a qualified teacher in order to help improve pupil outcomes, which is another attempt to raise the quality and status of the Early Years workforce.

\section{Leadership skills}

In the Teachers as Leaders Framework proposed by Crowther et al. (2009), teacher leadership requires skills such as problem solving, facilitating ability about pedagogical excellence, and translating ideas into action. However, Muijs and Harris (2007) argue that teacher leadership skills currently present in leaders already enable them to take initiatives and lead school improvement. Furthermore, Aubrey et al. (2013) noted that Early Years leaders had the leadership skills necessary to provide longterm goals for the successful outcomes for their pupils alongside a vision to ensure that every pupil acquired a positive start in life as enshrined in the Childcare Act (DfES, 2006). Therefore, this illustrated that Early Years leaders already possessed the change management skills needed to deal with change on a regular basis but remained uncertain as how to exercise them in a different context such as that beyond their age phase.

One fundamental skill required of leaders is an understanding of collaboration to govern complex problems, especially on how to transfer and integrate knowledge across participants to build long-term collaborative problem-solving capacity (Weber and Khademian, 2008). In the context of Early Years, aligning staff to buy into a new vision and creating coalitions for commitment requires motivating people through self-belief, working through and with people, which is a regular occurrence through the team-work approach in this age phase. Managing ambiguity in these larger teams requires specific skills of diplomacy and tact (Morrison and Glenny, 2011). According to Armstrong (2009: 8), this is evident in Early Years leaders as they had the skills to achieve tasks through the goodwill and support of people (influence) as a result of working with a wider range of staff, which is different from managers concerned with tasks alone.

Additionally, Armstrong talks about leadership skills that are associated with inspiring, influencing and guiding (Armstrong, 2009: 4), and the Virtual Staff College (2012) identified skills of political awareness and risktaking when leading a team. In addition, Branson (2006) focuses on sharpening leaders' knowledge, skills and abilities that promoted learning through a deeply structured reflective process. Interestingly, May's (2011) research undertaken with leaders of children's services suggested that the skills required by the next generation of leaders consisted of:

- creativity, ingenuity and skills of collaboration;

- entrepreneurial/business planning skills;

- ability to marshal resources and make best use of professional expertise; and

- confidence and courage to challenge orthodox solutions and to implement change in the face of opposition from the professional establishment.

But equally important when working with people in a team situation is the skill of what Grint (2010) calls a plan for likely resistance when trying to demonstrate the skills listed by May (2011). This is because all leaders at some point will have to deal with some form of resistance from their stakeholders (Armstrong, 2009; Fullan, 1992), and therefore it is important to have the right skills to deal with this diplomatically. Experiential learning according to Southworth (2002) offers opportunities for staff to create a sense of meaning of their learning, better promoted through social interaction with others (Crow, 2005). But not all staff feel comfortable to have an open dialogue and 'share their true feelings and opinions' about their shortcomings or other issues with their leaders (Retna and $\mathrm{Ng}$, 2016: 14). 
Reflecting on Hunzicker's (2012) research, carrying out leadership roles leads to growth and development professionally. Together, such conceptualizations suggest that teacher leadership development consists of three ideas, namely 'teacher participation, teacher learning and teacher influence' (Hunzicker, 2012: 276). Furthermore, WestBurnham suggests leadership is the catalyst to create 'community leadership' (West-Burnham, 2011: 171), where 'qualities rather than qualifications, expertise rather than experience, on ability rather than seniority' (ibid.) are valued. This model is different from the perceived existing model of hierarchy reinforced by perceived nuances of status. West-Burnham (2011) considers it is time to rethink educational leadership through a lens of community action validated by values of reciprocity, civic engagement, social networks, trust and moral leadership. Above all, new leaders need to demonstrate high levels of 'shared hope and aspiration' (West-Burnham, 2011: 170) for a better future. Next, the discussion moves onto what specialist skills Early Years leaders have that can be used to support others.

\section{Specialist leadership skills in Early Years}

Aubrey (2011: 13) suggested that there is a lack of leadership skills development within the context of Early Years, and this could be one reason why Early Years leaders may not consider themselves as leaders of learning and people. This section explores what specialist leadership skills Early Years leaders may have in leading learning and teaching.

There is a suggestion in the literature that teacher empowerment (by the head teacher) enhances greater participation in the leadership process to improve teaching and learning practices. Arguably, improved leadership skills reassure individuals to make judgements, take autonomous actions and act as change agents (Campbell, 2012; Lai and Cheung, 2015), as well as authorizing others as agents of change, which requires leaders to provide facilitative setting conditions. This could be undertaken by having open discussions and sharing information with teachers and other staff by leaders, but this might be constrained with busy operational and strategic duties (Murphy, 2005), especially in the context of Early Years. Senge (1996) also thinks dialogue is the key to this, where all can suspend assumptions to think together and work together effectively. Relevance and shared meanings are important to this process as change develops through incremental steps and needs time for adequate preparation and follow-up, where leadership skills to manage conflict and disagreement are a fundamental part of the process (Fullan, 1992). Moreover, communication is also a key feature of EYFS (DfE, 2014), with parents and other agencies as well as staff within the setting where there is greater diversity of staff teams, so meetings and discussions are crucial to share knowledge and ideas.

Change has a timetable of its own, but needs managing, and therefore requires strategic and operational skills. There are risks attached to systemic change, such as whole school policy, planning and implementation of the curriculum (EYFS, DfE, 2014), and delivering to tight deadlines, which may not allow proper consideration of all the issues. Coping with change on small or large scale at the required pace requires individual resilience, but this can only work if support is available from colleagues. Lai and Cheung (2015) investigated the leadership practices of teacher leaders who do not hold formal leadership roles and found that, when working together as a group, they have the potential to bring about positive educational change. They concluded that such collaborations bring about maximum chances for 'teachers to participate, to learn and to influence' (Lai and Cheung, 2015: 689). This concept of learning together is further advanced by Moller and Katzenmeyer (1996) and the EYFS (DfE, 2014) of staff sharing experience and expertise to improve practice.

We argue that any type of leadership skill development will be based on the needs of the setting, its context and the role that the head teacher themselves plays in catalysing change and growth of individual staff. Within Early Years, the leadership skills development appears to be dispersed across different team members and key stage coordinators which need to be better corralled for effective leading and managing of people and initiatives across the whole setting. This requires capacity building of teams and clusters within and across levels to achieve system-wide reform (Fullan, cited in O'Sullivan and West-Burnham, 2011: 23). It appears that system leadership is no longer a woolly abstract concept - 'it is at the heart of achieving deeply embedded reform on a wide scale' (ibid.).

\section{Using leadership skills to support other leaders}

Learning happens all around us, formally (by professional courses) and informally (learning sets, inter- and intracollaborations within and across settings). But not everyone is efficient or effective at learning and learning about how to learn together: 'learning, after all, is an admission of ignorance and imperfection' (Retna and $\mathrm{Ng}, 2016$ : 13). According to Gunter and Ribbins (2002: 12), staff who exchange ideas on effective learning through a culture of questioning 'the way we do things' on a daily basis offer greater opportunities for wider self-development than skills development alone. So, it is becoming clearer that leaders need to continue to consider flexible organizational structures for staff to meet individually or in teams to have an open dialogue and learn on the job to enhance their own leadership skills and of others.

Learning from each other to develop good practice may sound good in theory but has limited impact in driving professional development (Sebba et al., 2010), or really showing the impact of sharing of expertise, or seeing how to make better use of evidence leading to effective leadership or development (Greany, 2014). Zhang and Brundrett (2010: 154) suggest that leadership development should be better linked with 'theories of learning', the assumption being that leaders are best placed in their settings to reflect on their own learning and practice to make a difference to the end user being the pupil. According to Senge (1996) and Johnston and Caldwell (2001), where a setting sees itself as a learning organization this forms a good basis to 
exchange pedagogical ideas with each other, which is a key leadership skill, especially in the Early Years where more focus is on personalized pupil learning. One reason for this is the flatter hierarchical structures within Early Years settings, whereby practitioners undertake more teacher type roles such as observations, leading groups and planning, which tends to lead itself more naturally to an open and collaborative approach to leadership. There is also likely to be greater impact on self if the learning is personally meaningful during shared ideas, rather than imposed from a topdown, performance-driven target approach to development. This implies the need for greater creativity, imagination and a critical role by leadership to create the conditions for effective learning which are in the EYFS (DfE, 2014). However, this takes time and needs creative space by leaders for their team to learn if they are to facilitate 'critical and new ways of thinking and learning' (Retna and $\mathrm{Ng}$, 2016: 11).

Advances in leadership development point to collaborative modes of learning like joint practice development (Hargreaves, 2011), mentoring, coaching and apprenticeship underpinning social cultural theories. Above all, we believe that developing good relationships lies at the heart of good leadership development and how individuals take control of their own learning or through working closely with others. Zhang and Brundrett suggest that for developing new leaders, one needs to look at the individual context of the setting and consider 'more informal and experiential learning' (Zhang and Brundrett, 2010: 157) opportunities.

\section{Research questions}

Exploring the literature led to the investigation of the following research questions:

1. to explore what skills are necessary in being a good Early Years leader;

2. to identify from Early Years leaders what specific specialist leadership skills they feel they have in context of Early Years; and

3. to explore how these leadership skills can support other leaders in primary settings to have an impact on practice.

\section{Methodology}

A qualitative approach was used to collect ten case studies (Yin, 2003). Qualitative data from interviews was collected for subsequent coding for analysis against the three research questions. The data from the respondents offered robust descriptions of leadership roles and responsibilities and the qualities essential for Early Years leadership. These assisted the researchers in interpreting the data. The sample group consisted of ten Early Years practitioners (who led Early Years without being given the title of an Early Years leader) and ten Early Years leaders within primary schools, therefore 20 interviews were conducted in total. Early Years settings across the East Midlands and Bedfordshire regions were chosen on the basis of existing collaborative relationships between two Universities in England and their Early Years partners.

The intention of interviews was that they provide 'rich and relevant data' (Ribbins, 2007: 207). The size and range of the sample was small, so may not have given a basis for generalization (Muijs et al., 2004: 157), but did add new innovative knowledge in the context of Early Years through deep and rich data analysis to develop our argument (Holliday, 2003). A limitation of this study was its relative narrow scope of sample size; however, settings were chosen to achieve representativeness. Interviews were recorded and transcribed. Ethical issues were addressed thoroughly, including data security, safety and anonymity (BERA, 2004, 2011: online; Cohen et al., 2000). Data analysis was framed by the three research questions (Robins and Callan, 2009) using verbatim comments from participants throughout for illustrative purposes in relation to the case studies.

\section{Findings and discussion}

This section focuses on the impact of the findings from the interviews under the subheadings of the three research questions.

\section{To explore what skills are necessary in being a good Early Years leader}

In analysing the data, these were the emerging themes which characterized the good skills of an Early Years leader:

- good team-working skills

- good knowledge of child development

- multitasking - adaptable, flexible

- motivation

- good communication

- risk-taking

- being a good listener.

The skill of forming good relationships with all staff and parents was deemed a crucial requirement of any leader as Early Years practice relied heavily on team-work and team problem-solving approaches to achieve positive outcomes for pupils, as illustrated by one reception leader:

Essential to have good relationships and partnerships with parents and knowing how they can support the setting, working with the community is an essential part of my role. (Reception leader 3)

And another leader commented on the importance of developing other practitioners' skills:

To know what other staff need to help them develop - which is a skill, being able to identify the strengths of the team, being able to take risks by stepping out of role and allowing others to lead (like deputy head). Strong enabling skills are important to lead others (driving staff - lead and manage). (Reception leader 5) 
Staff in Early Years settings work closely with parents as they are the ones who can relay to the parents what pedagogical practice occurs and what they (the parents) can do to help teachers to achieve high standards for their pupils. Fullan (2002) calls for teachers' daily practices to be shared with different stakeholders to develop more of a shared understanding. According to Guskey (2000), teachers' experiences have an impact on teachers' attitudes and beliefs about teaching. It is through discussion and reflection that progress can be made allowing teachers ideas what Senge (1996) refers to as mental models - to be opened up for analysis and evaluation. Thus, the skills of creating trust and mutual respect amongst practitioners are of importance for honest behaviour for mutual learning. Good child development knowledge is imperative for effective leadership, as indicated by these comments by a reception leader:

In Early Years it is essential for someone who is able to understand the children they are with, to observe and identify their needs and adapt the teaching accordingly. To enhance children's learning through play and adult led through different stages of their development. (Reception leader 2)

Therefore, it is important for settings to support pupils as flexible learners. Cibulka et al. (2003) consider three key factors in developing flexible learners: how children learn, how to deepen learning and knowledge transfer (Vygotsky, 1978), and knowing learner aptitude. In the Early Years sector, staff are well aware of their pupil's interests, learning styles and levels. Hence, it could be argued that continuous professional learning for leaders has become a 'sine qua non' (O'Donoghue and Clarke, 2010: 7) if they are to remain current, as one reception leader noted:

Leaders have a holistic strategic role requiring vision and also developing other leaders through 'sitting and letting them have a go' so that they can identify needs. Leadership in Early Years is about having a passion for what you do. (Reception leader 10)

Shared vision and team learning form one of the five elements of Senge's (1996) idea of the learning organization. Such visualization is helpful in Early Years settings because there is often a team approach, a synergy to work together and an experience of interconnectedness and interrelationship (Silins et al., 2002). This suggests that leaders can develop such values for innovative practice through understanding the culture of the organization and managing it with sensitivity and care. On being a good leader, another reception leader commented:

Someone who has a caring, sensitive and fun rapport with the children. An excellent ability to communicate with adults and children and the ability to lead and inspire others. (Reception teacher 7, who is also a leader without the Early Years leader title)

West-Burnham suggests leadership is the catalyst to create 'community leadership' (West-Burnham, 2011: 171), where 'qualities rather than qualifications, expertise rather than experience, on ability rather than seniority' (ibid.) are valued. This model is different from the perceived existing model of hierarchy reinforced by perceived nuances of status. West-Burnham (2011) considers it is time to rethink educational leadership through a lens of community action validated by values of reciprocity, civic engagement, social networks, trust and moral leadership. Above all, new leaders need to demonstrate a high level of 'shared hope and aspiration' (West-Burnham, 2011: 170) for a better future. Perhaps Greenleaf's (1997) model of servant leadership with qualities of listening, empathy, awareness, persuasion, conceptualization, foresight, stewardship and building community are essential qualities of aspiring leaders, which we think Early Years leaders can demonstrate with support and encouragement. We turn next to the specialist leadership skills required by Early Years leaders.

\section{To identify from Early Years leaders what specific specialist leadership skills they feel they have in the context of Early Years}

The emerging themes transpiring from the data about specific skills from Early Years leaders were as follows:

- communication and knowledge of EYFS;

- building relations - as it shows trust and confidence;

- knowing your team well - so that they can carry out their role without supervision (trust);

- being assertive without being aggressive so that the setting moves forward;

- motivate the workforce as you are working with large teams; and

- gaining respect to build your professional reputation.

The notion of effective communication across and between different staff in Early Years is a strong emerging theme. This is unsurprising as the teachers and leaders provide a quality service (Aubrey et al., 2013) in meeting pupil needs through discussions in their key stages or across the key stages. Attributed closely to effective communication is slight evidence to support the view that regular discussions with team members motivate staff and show the fundamental importance of valuing others, as mentioned below:

Because you need to understand how people tick, to be aware of their needs to help in their role. Role of a leader is isolated so you need to know who you can rely on. The skills of being confident are important in order to be assertive (personalize issues to address needs rather than making a person feel attacked) and one way is through communicating as best as you can. (Reception leader 9)

The leadership role had direct responsibilities for planning, organizing, teaching, coordinating teams, assessing, recording and reporting of children's progress (Rhodes and Brundrett, 2010). Much of the leadership and management duties therefore merged into one, so it is understandable 
why Early Years leaders did not recognize their role or specialist skills lying in leadership and management; rather, it was more focused on a teaching role to raise achievement to meet setting priorities (Muijs et al., 2004). One teacher leader commented:

I want to capture pupils' imagination and challenge their abilities through my teaching role. (Reception teacher 6, who is also a leader without the Early Years leader title)

Furthermore, in both task- and person-centred activities, these Early Years leaders were far more immersed in the daily frantic pace of the setting to get jobs done. It was this high intensity and pace (Aubrey, 2011: 52) that demonstrated how skilled and adept they were at multitasking and meeting the needs of a wider-ranging workforce which earned them respect and trust. One leader noted:

To help gain the respect of those you work with. It's about being a good leader to make your setting successful. These skills help you to be confident and competent in the Early Years community so that you are recognized for the good work you do. (Reception teacher 4, who is also a leader without the Early Years leader title)

The perceptions of what defines leadership and the specialist skills associated with it prompted various responses depending on the experience and length of service each respondent had. But the key theme seemed to be good people management skills (Morrison and Glenny, 2011) and providing the highest-quality education for the pupils in their care, as noted by this comment:

These skills are important because they underpin the effectiveness and the success of the EYFS department. If it isn't led by someone who has vision, good knowledge and interpersonal skills, then it is hard to promote the uniqueness of EYFS and the potential it offers children as the basis of their educational experiences. (Reception leader 1)

Aubrey found a number of common leadership themes that mirrored our findings, namely, 'values and needs of the Early Years phase, raising achievement, being a role model, setting the standard, leading others, managing change and juggling and balancing' (Aubrey, 2011: 41). These personal qualities and values were seen as important in leadership, especially leadership skills that involved making judgements as an autonomous change agent (Campbell, 2012; Lai and Cheung, 2015). However, Aubrey (2011: 43) noted that decision-making is often at the team level and collaborative, as illustrated by these leaders' comments:

We carry out observations and identify what they do well as a way of sharing good practice and then we also suggest what needs to be improved through discussions - in this way this is a form of professional development. (Reception leader 8)

By understanding team strengths and weaknesses and supporting them when needed. I also spend time monitoring other staff to recognize skills of admin staff too, so that they can support the setting more. (Reception teacher 9, who is also a leader without the Early Years leader title)

Sometimes it appears that the leader has quite a power to make decisions, as noted by Aubrey, quoting a research participant who said, 'I am a very powerful person' (Aubrey, 2011: 43). Getting a sense of collaboration is not an easy task, and requires creating an enabling environment which 'nurtures trusting relationships and values individuals' (Robins and Callan, 2009: 20):

You are building bonds with children, staff and parents. (Reception teacher 8, who is also a leader without the Early Years leader title)

Earlier, we alluded to the fact that schools are complex organizations with different roles and functions carried out by different actors. These roles (e.g. head teacher, teacher, pupils) are institutional and embodied, and have the potential to be reconstructed (Thompson and Gitlin, 1995). Sometimes, the standing forms of power remain in place, 'a space is created in which the roles and relationships involved may be problematized so as to effect new possibilities' (ibid: 131). In other words, in a new world of collegiality, partnerships and collaborations, arguably we need to have multiple conversations to transform action toward new possibilities away from power relations. Rusch focused on relationships and reciprocity, on people learning 'with each other rather than from each other' (Rusch, 2005: 9); here, there is no discourse about power.

Given the changing global context and 'changing culture in organizations' (Aubrey, 2011: 46) has suggested that leaders in the Early Years setting are having to change and are more adaptable and learning to better manage the external and internal influences requiring continuous training and professional development. As one leader remarked,

We are asking questions and comparing ideas ... which means we are being more confident and trusting of each other to change our working ways for the better. (Reception teacher 1, who is also a leader without the Early Years leader title)

As Fullan (2005) notes, to build capacity, there has to be leadership development. This means further developing Early Years leader's skills, abilities, knowledge and understanding about excellence in pedagogy and nurturing human relationships. They have to believe that they too can be excellent leaders as 'you need to learn it by doing it' (Fullan, 2005: 69). We now turn to our third theme.

\section{To assess how these leadership skills can support other leaders in primary settings to have an impact on practice}

It remains a real challenge to link claims about the impact of leadership on others or learning or on pupil attainment. Guskey's typology of impact is used here to provide a conceptual framework. Guskey's (2000) typology of impact offers five levels, ranging from participants' 
reactions to pupil learning outcomes. We see from the evidence data that all five of Guskey's levels are indicated to some degree or other. For example, at level 1, teachers asked for greater personal needs to be recognized, which required leadership to provide support and change to affect this need (level 3). What they had learned (level 2) from coaching or mentoring to develop their leadership skills became evident when they practised such skills with and through team members or individually using new-found knowledge and skills (level 4). The passion to improve the educational outcomes of their pupils (level 5) was the ultimate goal, but this would be hard to assess from this study alone.

The emerging themes from the data about how Early Years leader's skills can support others in a primary setting consisted of:

- need to build better and lasting relationships with parents;

- personalized learning to help raise attainment;

- leading other team members; and

- enthusiasm and passion for what you do is visible.

This is limited given the complexity of learning challenges faced in Early Years settings. The greatest strength among staff in Early Years and their leaders is that of working with people. In Early Years settings, leaders work closely with other colleagues, liaise with parents, and plan and lead learning for children. So they have developed sharp skills of listening to parents leading to greater supportive culture between home and school. Such good relationship-building arguably impacts children's learning (Sebba et al., 2010).

One leader observed:

In EYFS there is often a team of staff led by one member of staff. This person also liaises with parents and families and other agencies. So we develop good relationships with different people to support our pupils. (Reception leader 6)

Another leader remarked:

You have to build positive partnerships with parents very quickly in the early years as we liaise with parents every day - something that does not happen as much in the primary sector - so you have to have the skills of communication sector. (Reception leader 4)

By working together as a team, each member understands an individual pupil's needs and plans the learning in a personalized way (DfES, 2006), which takes the pressure away from the class teacher. The support staff are used efficiently to help maximize learning, but it is important to note that this responsibility ultimately rests with the class teacher.

It is standard practice to personalize the learning for children. Learning is more personalized in the Early Years through experiences and play and therefore we know our children very well, again something that is missing in the primary sector
(Reception teacher 2, who is also a leader without the Early Years leader title)

This practice differs from the primary phase because Early Years settings offer greater opportunities for the team to empathize with different needs of pupils and as pupils get older and progress to the primary phase they are encouraged to be more independent in thinking and learning. When the leaders work with colleagues in Early Years, they utilize different skills of communication with a wide range of teams with different qualifications supporting the pupils in their care (Bricker, 2000). So these leaders may have to show a nursery nurse or a teaching assistant or a key worker how to plan, support and assess the pupils they work with. It then becomes important for leaders to demonstrate high emotional literacy to foster and empower relationships in teams (Robins and Callan, 2009: 114-115).

There are several models of developing leaders in the twenty-first century, with collaboration being a key component of development that is seen in various models like apprenticeship. What the literature suggests is that school context matters, taking account of external, national indicators of change. Each school will have their own policy to develop staff on different levels of the career ladder and aspirations. What this research demonstrates is that leadership should be widely distributed and that a central role of the head teacher is to develop the leadership capability of other staff using a variety of leadership development approaches.

Through greater interaction, the team works together to have an impact on pupil progress and attainment. Many similar views about the need to lead other members were offered:

The skills of an EYFS leader are interchangeable with those of wider leadership roles. So I lead other members through coaching and mentoring colleagues and trainee students by building links with other units, sharing good practice. (Reception leader 7)

By understanding team strengths and weaknesses and supporting them when needed. I also spend time monitoring other staff to recognize skills of admin staff too, so that they can support the setting more. (Reception teacher 3, who is also a leader without the Early Years leader title)

We carry out observations of staff and identify what they do well as a way of sharing good practice, and then we also suggest what needs to be improved through discussions - in this way this is a form of professional development. (Reception leader 7)

Indeed, Robins and Callan (2009) note that team members look to their leaders to inspire and guide them and reflect on Rodd's ideas about good leadership skills (Rodd, 2006: 37, cited in Robins and Callan, 2009: 115) as a person who shows 'compassion (creating trust, empathy, high expectations, hope and inspiration and providing opportunities for individual, group, personal and professional development)'. 
The skills, knowledge and understanding of Early Years leaders defined by Rodd (2006) mirror the attitudes of staff who work in the Early Years phase to promote a highquality Early Years vision. Their passion and central focus on child-centred education remains the steadfast rule that must not be tossed off in the face of adversity and constant educational turmoil.

Being a leader is an immense responsibility requiring curiosity, courage, honesty (Rodd, 2006), as well as an ability to show enthusiasm and passion for what you do. Passionate leadership is about 'energy, commitment, a belief that every child can learn and will learn... (which) inspires their staff and transform children's lives' (Davies and Brighouse, 2010: 4). The quote below shows the need to be a role model to have an impact on the setting, staff and pupils:

Parents can see my enthusiasm and therefore they can see that I really care about their children which is important to me as a leader. I demonstrate this as a role model through continuous learning (by doing various courses) to up-skill myself and also help to raise the standards of qualification so that we are learning together, leading to system leadership and succession planning. So the impact on adults is via direct support given to all staff.

The impact on children is a safe and secure environment created so that children enjoy coming to school. We are finding that more children are coming from other settings to us due to our growing good reputation (positive impact at home of the children coming to this setting) - choosing quality, and therefore impact is through supporting partnership. (Reception leader 4)

Early Years leaders have a range of leadership skills that are at times embedded within them naturally and therefore they do not realize that these are key leadership skills. Current pressures in all settings in terms of raising attainment to increase pupil outcomes means that Early Years have to fulfil the top-down priorities imposed on them. The missing link is that Early Years leaders have a whole range of people skills that support partnership and other stakeholders from a leadership perspective, but which is not recognized as they work with young pupils, where at times pupil results are not valued (Rodd, 2006).

\section{Conclusions}

In conclusion, Early Years leaders had a range of specialist leadership skills to support pedagogy and practice as it underpinned the success of the Early Years phase. The key specialist skill in this phase was knowing pupils very well so that learning can be personalized to help improve outcomes. This implied that the impact of these leadership skills such as clear vision, secure knowledge and effective interpersonal skills needed to be shared beyond the Early Years phase in terms of linking ideals to practice. The findings also showed there was capacity and willingness for Early Years leaders to take on more leadership roles that reflected their experience, expertise and hunger for the role and a commitment to leadership for learning. We also found that some Early Years leaders' skills were not fully utilized beyond leading in the Early Years, hence missing an opportunity to unlock potential for wider impact. This suggested the need for goal-setting dialogue to share good practice, to model effective leadership styles and to identify potential leadership skills of others in the setting.

A number of recommendations arise from the study:

- educating through dialogue and active, critical enquiry;

- creating an inclusive learning community;

- making connections across the setting, units and other children's centres;

- creating innovative practice that mirrors excellence about leadership for learning;

- equipping children to have a critical and inquiring voice;

- exploring critically the examples of leadership practice in Early Years globally; and

- engaging children and parents as partners in their education, and as co-producers of knowledge in improving the experiences of both children and staff.

Our on-going investigation is only a small-scale study that could be scoped up to get greater in-depth data for comparative analysis. Further study could also look at larger samples and more networking to share good practice on effective leadership for effective learning outcomes to have an impact on practice.

\section{Acknowledgements}

The authors would like to thank BELMAS for their financial support.

\section{Declaration of Conflicting Interests}

The authors declared no potential conflicts of interest with respect to the research, authorship and/or publication of this article.

\section{Funding}

The authors received no financial support for the research, authorship and/or publication of this article.

\section{References}

Armstrong M (2009) Armstrong's Handbook of Management and Leadership: A Guide to Managing for Results (2nd edn). London: Kogan Page.

Aubrey C (2011) Leading and Managing in the Early Years (2nd edn). London: SAGE, 7-38.

Aubrey C, Godfrey R and Harris A (2013) How do they manage? An investigation of early childhood leadership. Educational Management Administration Leadership 41(1): 5-29.

Branson C (2006) Effects of structured self-reflection on the development of authentic leadership practices among Queensland primary school principals. Educational Management Administration \& Leadership 35(2): 227-248.

British Educational Research Association (BERA) (2004) Revised ethical guidelines for educational research. Available at: 
www.bera.ac.uk/files/guidelines/ethica1.pdf (accessed March 2014).

British Educational Research Association (BERA) (2011) Ethical guidelines for educational research. Available at: http: guidelines on http://content.yudu.com/Library/A1t9gr/BERAEthi calGuideline/resources/index.htm? referrerUrl $=\mathrm{http} \% 25253 \mathrm{~A}$ $\% 25252 \mathrm{~F} \% 25252 \mathrm{Fwww} . y u d u . c o m \% 25252$ Fitem $\% 25252 \mathrm{~F}$ details\%25252F375952\%25252FBERA-Ethical-Guidelines2011 (accessed November 2014).

Bricker D (2000) Interdisciplinary Early Intervention/Early Childhood Special Education Leadership Program: Final Report. Eugene, OR: Oregon University, Eugene College of Education

Brundrett M, Fitzgerald T and Sommefeldt D (2006) The creation of national programmes of school leadership development in England and New Zealand: A comparative study. International Studies in Educational Administration 34(1): 89-105.

Bush T (2015) Teacher leadership: Construct and practice. Educational Management Administration \& Leadership 43(5): 671-672.

Campbell E (2012) Teacher agency in curriculum contexts. Curriculum Inquiry 42(2): 183-190.

Cibulka J, Coursey S, Nakayam M, Price J and Stewart S (2003) Schools as Learning Organizations: A Review of the Literature. Nottingham: National College for School Leadership. Available at: http://www.ncsl.org.uk/ncl (accessed 20 March 2013).

Cohen L, Manion L and Morrison K (2000) Research Methods in Education (5th edn). London: RoutledgeFalmer.

Crow G (2005) Developing leaders for schools facing challenging circumstances. In: Coles MJ and Southworth G (eds) Developing Leadership: Creating the Schools of Tomorrow. Maidenhead, UK and New York, NY: Open University Press.

Crow G (2006) Complexity and the beginning principal in the United States: Perspectives on socialisation. Journal of Educational Administration 44(4): 310-325.

Crowther F, Ferguson M and Hann L (2009) Developing Teacher Leaders: How Teacher Leadership Enhances School Success (2nd edn). Thousand Oaks: Corwin.

Davies B and Brighouse T (2010) Passionate leadership. Management in Education 2(4): 4-6.

Department for Education and Skills (DfES) (2006) Childcare Act. London: DfES.

Department for Education (DfE) (2014) Statutory Framework for the Early Years Foundation Stage (EYFS). London: DfE. Available at: https://www.gov.uk/government/uploads/sys tem/uploads/attachment_data/file/335504/EYFS_framework_ from_1_September_2014__with_clarification_note.pdf (accessed March 2016).

Freeman NK and Brown MH (2000) Evaluating the child care director: The collaborative professional assessment process. Young Children 55(5): 20-26.

Fullan M (1992) The New Meaning of Educational Change. London: Cassell.

Fullan M (2002) The change leader. Educational Leadership 59(8): 16-21.

Fullan M (2005) Leadership and Sustainability. London: SAGE. Greany T (2014) Are We Nearly There Yet? Progress and Next Steps Towards a Self-Improving School System. London: Institute of Education.
Greenleaf R (1997) Servant Leadership: A Journey into the Nature of Legitimate Power and Greatness. New York: Paulist Press.

Grint K (2010) Leadership: A Very Short Introduction. Oxford; New York: Oxford University Press.

Gunter H and Ribbins P (2002) Leadership studies in education: Towards a map of the field. Educational Management and Administration 30(4): 378-416.

Guskey T (2000) Evaluating Professional Development. Thousand Oaks: CA, Corwin Press.

Hargreaves DH (2011) Leading a Self-Improving School System. Nottingham: National College for School Leadership.

Holliday A (2003) Doing and Writing Qualitative Research. London: SAGE.

Howland G (2013) BELMAS Research Programme: Leadership Preparation and Development: An investigation into leadership preparation in two primary schools. Final Report, December 2013. Visit belmas.org.uk.

Hunzicker J (2012) Professional development and job-embedded collaboration: How teachers learn to exercise leadership. Professional Development in Education 38(2): 267-289.

Johnston C and Caldwell B (2001) Leadership and organisational learning in the quest for world class schools. The International Journal of Educational Management 15(2): 94-102.

Lai E and Cheung D (2015) Enacting teacher leadership: The role of teachers in bringing about change. Educational Management Administration \& Leadership 43(5): 673-692.

May A (2011) Tomorrow will not be the same as today. PowerPoint presentation by the Corporate Director for Children and Young People. ALICSE programme, Nottinghamshire County Council. Nottingham: SDSA.

Mistry M and Sood K (2015) English as Additional Language in the Early Years: Linking Theory to Practice. Oxford: Routledge.

Moller G and Katzenmeyer M (eds) (1996) Every Teacher as a Leader: Realizing the Potential of Teacher Leadership. San Francisco: Jossey-Bass.

Morrison M and Glenny G (2011) Collaborative interprofessional practice: In search of evidence. The BELMAS International Conference, Wyboston Lakes, Milton Keynes, 8-10 July.

Moyles J (2006) Effective Leadership and Management in the Early Years. London: Oxford University Press.

Muijs D and Harris A (2007) Teacher leadership in (in)action. Educational Management Administration \& Leadership 35(1): 111-134.

Muijs D, Aubrey C, Harris A and Briggs M (2004) How do they manage? Research on leadership in early childhood. Journal of Early Childhood Research 2(2): 157-169.

Murphy J (2005) Connecting School Leadership and School Improvement. Thousand Oaks: Corwin Press.

Nutbrown C (2012) Foundations for quality: The independent review of early education and childcare qualifications. Final report. London: Department for Education.

O'Donoghue T and Clarke S (2010) Leading Learning: Process, Themes and Issues in International Contexts. London: Routledge.

O'Sullivan $\mathrm{H}$ and West-Burnham J (eds) Leading and Managing Schools. London: SAGE. 
Retna KS and Ng PT (2016) The application of learning organization to enhance learning in Singapore schools. Management in Education 30(1): 10-18.

Rhodes C and Brundrett M (2010) Leadership for learning. In: Bush T, Bell L and Middlewood D (eds) The Principles of Educational Leadership \& Management (2nd edn). London: SAGE.

Ribbins P (2007) Interviews in educational research: Conversations with a purpose. In: Briggs A and Coleman M (eds) Research Methods in Educational Leadership \& Management (2nd edn). London: SAGE, 207-223.

Robins A and Callan S (eds) (2009) Managing Early Years Settings. London: SAGE.

Rodd J (1996) Towards a typology of leadership for the early childhood professional of the 21st century. Early Childhood Development and Care 120: 119-126.

Rodd J (2006) Leadership in Early Childhood (3rd edn). Buckingham: OUP.

Rusch EA (2005) Institutional barriers to organizational learning in school systems: The power of silence. Educational Administration Quarterly 41(1): 83-120.

Sackney L and Walker K (2006) Canadian perspectives on beginning principals: Their role in building capacity for learning communities. Journal of Educational Administration 44(4): 341-358.

Sebba J, Kent P and Tregenza J (2010) Joint Practice Development: What Does the Evidence Suggest are Effective Approaches? Nottingham: National College for School Leadership.

Sellgren K (2016) Toddlers 'need early years teachers in nurseries'. BBC Education. Available at: http://www.bbc.co.uk/ news/education-35917037 (accessed March 2016).

Senge P (1996) The Fifth Discipline: The Art and Practice of the Learning Organisation. Sydney: Random House.

Silins H, Zarins S and Mulford B (2002) What characteristics and processes define a school as a learning organization? Is this a useful concept to apply to schools? International Education Journal 3(1): 24-32.

Simpson D (2015) A UK-US investigation of early education practitioners' opinions about child poverty and its prioritizing within their practice. Social Futures Institute, Teesside University, UK.

Southworth G (2002) Instructional leadership in schools: Reflections and empirical evidence. School Leadership and Management 22(1): 73-91.

Teather S (2011) EYP and new leaders training to continue. Nursery World, 26 January. Available at: http://www.nursery world.co.uk (accessed February 2016).

Thompson A and Gitlin A (1995) Creating spaces for reconstructing knowledge in feminist pedagogy. Educational Theory 45(2): 125-150.

Tickell C (2011) The Early Years: Foundations for Life, Health and Learning. An Independent Report on the Early Years Foundation Stage to Her Majesty's Government. London: Department for Education.

Virtual Staff College (2012) Leading Learning Organisations: How the Intelligent Leader Builds Capacity. Nottingham: Virtual Staff College.

Vygotsky LS (1978) Mind and Society. Cambridge, MA: Harvard University Press.
Weber EP and Khademian AM (2008) Wicked problems, knowledge challenges, and collaborative capacity builders in network settings. Public Administration Review 68: 334-349.

West-Burnham J (2011) Rethinking educational leadership. In: O'Sullivan $\mathrm{H}$ and West-Burnham $\mathrm{J}$ (eds) Leading and Managing Schools. London: SAGE.

Yin RK (2003) Case Study Research: Design and Methods (3rd edn). Thousands Oak: SAGE.

Zhang W and Brundrett M (2010) School leaders' perspectives on leadership learning: The case for informal and experiential learning. Management in Education 24(4): 154-158.

\section{Author biographies}

Malini Mistry is a senior lecturer in Early Years Education and Professional Studies and Head of Year 2 at the University of Bedfordshire with research interest in English as an Additional Language and Early Years.

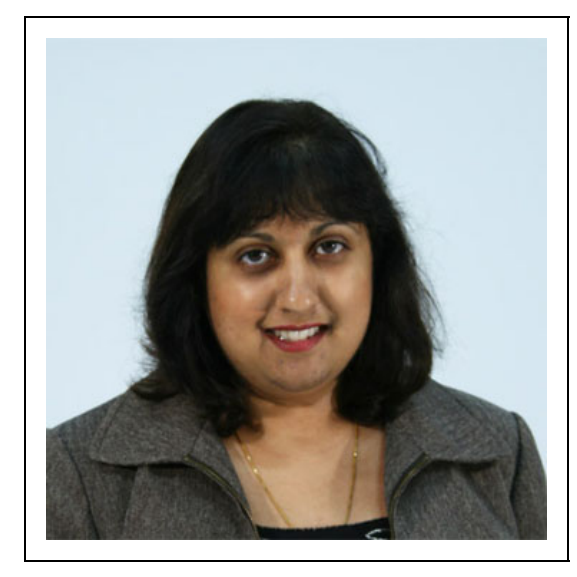

Krishan Sood is senior lecturer in Education in the School of Education at Nottingham Trent University. He has been a Science teacher and advisor, and worked in four universities in UK in the field of educational leadership and management and equal opportunities. He has conducted numerous projects researching equality, gender and early years leadership. [Email: krishan.sood@ntu.ac.uk]

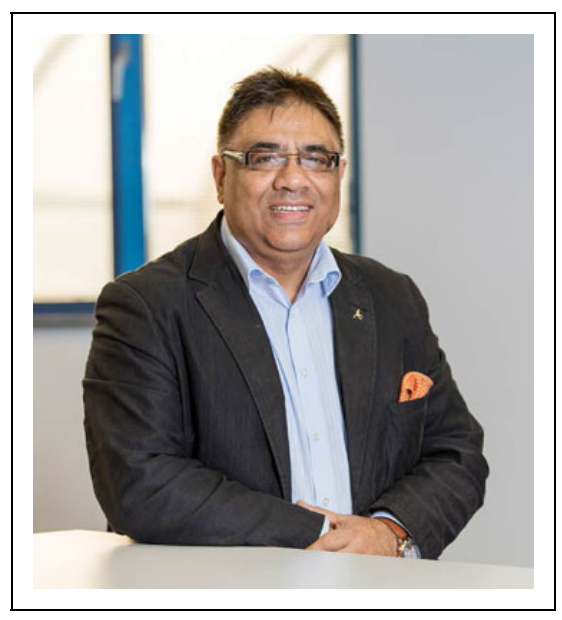

